\title{
Katarzyna Woźniak \\ Ku teatrowi agonistycznemu. Pippa Delbona Waleczność rycerska w Teatrze San Carlo
}

\begin{abstract}
Katarzyna Woźniak, Ku teatrowi agonistycznemu. Pippa Delbona Waleczność rycerska w Teatrze San Carlo [Towards the Theater of Agon. Pippo Delbono's Cavalleria rusticana at San Carlo Theater]. „Przestrzenie Teorii” 36. Poznań 2021, Adam Mickiewicz University Press, pp. 153-162. ISSN 1644-6763. DOI 10.14746/pt.2021.36.9.
\end{abstract}

The author aims to outline the dramatic work of the Italian director Pippo Delbon as establishing a theater of agon. From the state of research, she analyzes the staging of Pietro Mascagni's Cavalleria rusticana and formulates the theory of Delbonos's theater of agon based on M. de Certeau's and W. Świątkowska's papers and the theories of dramaturgy of Anna Krajewska and Dariusz Kosiński.

KEYWORDS: Pippo Delbono, agonistic theater, Cavalleria rusticana, dramaturgy

Pippo Delbono jest artystą totalnym: z powodzeniem reżyseruje spektakle operowe i teatralne, tworzy filmy dokumentalne, artystyczne fabuły i poetyckie miniatury. Warsztat aktorski szlifował u Ryszarda Cieślaka. Grał u Piny Bausch. Partnerował Tildzie Swinton w wysokobudżetowej produkcji Jestem miłościq w reżyserii Luki Guadagnina. Eseista i poeta. Wrażliwy, wnikliwy, bezlitosny komentator życia społecznego i jednostkowego. Autoironiczny skrutator zakamarków własnej duszy. Buddysta. Pisze się o nim we Włoszech: wizjoner, fuori dai canoni - nieszablonowy reżyser, który stworzył oryginalny język sceniczny. On sam nieustannie podkreśla, że ukształtowały go taniec i Trzeci Teatr, a fascynował Kantor, do którego lubi się porównywać.

Delbono-dramaturg, świadomy performatywnej natury dramatu, każdorazowo definiuje go na nowo i ustanawia na scenie; wskazuje widzowi palcem (dosłownie) na wzajemna, zmienną relację dramatu i wyborów dramaturga i żąda, by widz nie pozostał obojętnym wobec faktu istnienia relacji opartej na subiektywnych wyborach, które wpływają na jego własne spojrzenie na rzeczywistość.

W kolejnych częściach tekstu postaram się nakreślić ramy pracy dramaturgicznej Delbona jako ustanawiania teatru agonistycznego, począwszy od stanu badań, po wskazanie narzędzi metodologicznych przydatnych do dalszych analiz, w odniesieniu do wybranego aspektu pracy Delbona, to znaczy krytyki instytucji teatralnych, której pierwszym polem była insce- 
nizacja Rycerskości walecznej Pietra Mascagniego. Z konieczności rezygnuję z pogłębionych analiz i poruszania kolejnych wątków ${ }^{1}$, na które w opracowaniu tak skromnych rozmiarów zwyczajnie nie ma miejsca.

\section{Stan badań}

Powiedziałabym, że stan badań nad twórczością Delbona we Włoszech jest płynny, a kolejni mierzący się z nią autorzy są niejako pogodzeni z klęską takiego projektu. Już pobieżny przegląd najważniejszych pozycji włoskojęzycznych pozwala wskazać ogólne tego przyczyny. Zarówno książka La possibilità della gioia ${ }^{2}$ Gianniego Manzelli, jak i Visioni incociate. Pippo Delbono tra cinema e teatro ${ }^{3}$ Nicoli Biondy i Chiary Gualdoni, pretendujace do miana całościowych opracowań, trudno uznać za takie przynajmniej z dwóch powodów. Po pierwsze, autorzy w stosunkowo krótkiej formie (książka Manzelli liczy 220 stron, a opracowanie Biondy i Gualdoni ledwie 60) proponują czytelnikowi przebieżkę przez różne formy twórczości reżysera $^{4}$. Nagromadzenie tytułów, dat, nazwisk i referencji zamiast rozjaśniać obraz, tylko go zaciemnia. Po drugie, autorzy pozostają wierni hermeneutyce przyjaźni: choć w niektórych przypadkach nie można odmówić im trafności spostrzeżeń (przede wszystkim dotyczących twórczości filmowej artysty, w znacznie mniejszym stopniu jego twórczości teatralnej), trudno ich posądzać o stworzenie dla nich odpowiedniej podbudowy teoretycznej. I tak z jednej strony będziemy napotykać w nich nieco już anachroniczne nawiązania do warsztatu Eisensteina czy do teatru epickiego Brechta jako modelu włoskiego teatru zaangażowanego drugiej połowy XX wieku, z drugiej zaś - poetyckie metafory, które być może trafnie ujmuja sedno poszczególnych spektakli, okazują się jednak mało przydatne w analizie modelu dramaturgicznego. Lektura przedmiotowych książeczek pozwala stwierdzić, że mamy raczej do czynienia z esejami krytycznoteatralnymi niż z opracowaniami naukowymi. W tym miejscu wypada dodać, że włoska teatrologia późno przyswaja najnowsze propozycje teoretyczne światowych performance studies. Dla przykładu: przekład książki Eriki Fischer-Lichte

${ }^{1}$ Chodzi między innymi o ciało i seksualność, stosunek zbiorowości do jednostki i jednostki do zbiorowości oraz tożsamość kulturową i etniczną.

${ }^{2}$ G. Manzella, La possibilità della gioia, Firenze 2017.

${ }^{3}$ N. Bionda, C. Gualdoni, Visioni incociate. Pippo Delbono tra cinema e teatro, Corazzano (Pisa) 2011.

${ }^{4}$ Trzecia włoska monografia poświęcona Delbonowi, mniej ambitna w swoich założeniach, bo autorka zawęża temat do problematyki ciała, jest utrzymana w podobnym duchu. Chodzi o album Pippo Delbono. Corpi senza menzogna Leonetty Bentivoglio. Zob. L. Bentivoglio, Pippo Delbono. Corpi senza menzogna, Firenze 2009. 
Estetyka performatywności ukazał się w 2014 roku, Teatr postdramatyczny Hansa-Thiesa Lehmanna - w 2017 roku, a Performatyka Richarda Schechnera - dopiero w 2018. Trudno oczekiwać, by te teorie zostały w krótkim czasie przyswojone i mogły zmienić obowiązujący dyskurs, kształtowany w głównej mierze przez rodzimą szkołę teoretyczną. Pod tym względem polskie badania nad teatrem i dramatem czy szerzej - właśnie nad performance studies - sa o wiele bardziej „światowe”. Tymczasem, gdy - parafrazując słynne i nieco już zużyte zdanie Schechnera - postawimy pytanie teoretyczne o to, co robi Delbono-dramaturg, kiedy pracuje, będziemy mieli szansę wskazać, że realizacja postulatów formułowanych w warstwie słownej przedstawień odbywa się w liminalnych czasie i przestrzeni, pomiędzy „tu i teraz” przedstawienia a „tu i teraz” widzów, i jest możliwa dzięki zastosowaniu konkretnych narzędzi dramaturgicznych. Tę granicę wyznacza Pippo Delbono - postać/niepostać własnych spektakli. Spojrzenie na „życie w sztuce" Delbona z perspektywy zagranicznej nie tylko jest potrzebne, lecz wydaje się konieczne.

\section{Rycerskość wieśniacza}

Delbono nie jest i nigdy nie był artystą niszowym. Choć na początku kariery tworzył inscenizacje skromnych rozmiarów w duecie z Pepe Robledem (np. Il temo degli assassini z 1987 roku czy Morire di musica z 1988), jego znakami rozpoznawczymi już na przełomie lat osiemdziesiątych i dziewięćdziesiątych stały się dzieła monumentalne, wielogłosowe partytury na orkiestrę aktorów, której jest dyrygentem. Koncertowa metafora jest tu jak najbardziej uzasadniona, ponieważ obok teatru dramatycznego to deski najstarszego teatru operowego stały się polem bitwy o nowy teatr instytucjonalny (rozgrywanej później na największych scenach dramatycznych w kraju i za granica, m.in. we Francji i w Chorwacji), a pierwszym zdobytym przyczółkiem była Rycerskość wieśniacza Pietra Mascagniego.

Premiera pierwszej opery wyreżyserowanej przez Delbona nastapiła w lipcu 2012 roku w Teatrze San Carlo w Neapolu. Ten teatr - najstarsza operowa scena świata, działająca z krótkimi przerwami od 1737 roku - zapisał się w historii włoskiej opery jako arena walki o suwerenność teatru, „który się wtrąca” co najmniej od połowy XIX wieku, gdy próbowano cenzurować opery narodowego wieszcza Giuseppe Verdiego (niedopuszczenie do premiery Trubadura w 1853 roku i Balu maskowego w 1959). W dużym uproszczeniu moglibyśmy powiedzieć, że jeśli opera, o czym byli przeświadczeni wszyscy architekci „,wielkich Włoch” od risorgimento po faszyzm, w najwyższym stopniu wyraża ducha narodu włoskiego, to w neapolitańskim San 
Carlo stoczono jedne z najważniejszych walk o to, jak ten duch miałby być kształtowany. Inscenizacja Delbona wpisuje się w tę tradycję.

Rycerskość wieśniacza Mascagniego - największy sukces włoskiego kompozytora - to wyjątkowo dobrze przyjęte przez publiczność przeniesienie na deski opery cieszącej się ogromną popularnością (głównie za sprawą wybitnej kreacji Eleonory Duse) sztuki Giovanniego Vergi pod tym samym tytułem. Inicjatorem operowej adaptacji był Giovanni Targioni-Tozzetti i to on - razem z Guidem Menascim - napisał libretto do muzyki toskańskiego kompozytora. Opera miała swoją premierę w Rzymie 17 maja 1890 roku. Okazała się nie tylko ogromnym sukcesem kasowym; zapoczątkowała też tzw. Giovane scuola - nową szkołę opery włoskiej, do której zalicza się między innymi twórczość Giacoma Pucciniego i Ruggera Leoncavalla. Zasadniczo uznaje się ją także za pierwszą włoską operę werystyczna, choć mając na uwadze sielankowy, plebejski krajobraz sycylijskiej wsi wykreowany przez pierwszych inscenizatorów, należałoby raczej zrewidować ten pogląd, co wykracza poza przedmiot moich rozważań.

Rzecz rozgrywa się w Wielkanoc w małej sycylijskiej wiosce, która u Mascagniego przeradza się w niemal idylliczna krainę. Lola, narzeczona Turiddu, pod jego nieobecność wychodzi za mąż za Alfia. Gdy zdradzony narzeczony wraca w rodzinne strony po odbyciu służby wojskowej, postanawia wzbudzić zazdrość w Loli i uwodzi Santuzzę. Intryga przynosi zamierzony skutek: zazdrosna Lola wdaje się w romans z Turiddu. Santuzza, nie mogąc nakłonić Turiddu do zmiany postępowania i na próżno szukająca pomocy u jego matki, postanawia w końcu zdradzić Alfiowi sekret kochanków i tym samym ściaga na Turiddu śmierć. Za najważniejsze zmiany wprowadzone przez Mascagniego, Tragioniego-Tozzettiego i Menasciego względem struktury dramatu Vergi wypada uznać przesunięcie akcentów z werystycznego odmalowania sycylijskiej wsi na perypetię miłosną i ograniczenie roli chó$\mathrm{ru} \mathrm{z}$ rezonatora do narratora, a w warstwie inscenizacyjnej - rezygnację $\mathrm{z}$ baletu.

Do premiery przedstawienia w reżyserii Delbona doszło 17 lipca 2012 roku $^{5}$. Reżyser wystawił operę zasadniczo bez skrótów. Wprowadził do niej charakterystyczny dla siebie odautorski prolog na temat straty i żałoby oraz przeplótł tekst libretta opowieściami z własnego życia ('śmierć matki w 2011 roku i związane z nią wydarzenia) i cytatami (m.in. z tekstów Ungarettiego). W warstwach inscenizacyjnej i scenograficznej dokonał natomiast dwóch znaczących przesunięć: scenografia Sergia Tramontiego,

${ }^{5}$ Dyrygenci: Pinchas Steinberg i Maurizio Agostini, chórmistrz: Salvatore Caputo, kostiumy: Giusi Giustino, scenografia: Sergio Tramonti, Santuzza: Oksana Volkova, Turiddu: Stuart Neill \Francesco Anile (19 lipca), Lucia: Elena Zilio, Alfio: Ambrogio Maestri \Bruno Iacullo (18-19 lipca), Lola: Giuseppina Piunti, Bobò. 
zbudowana z monumentalnych, rdzawych ścian zamykających scenę z trzech stron, wzdłuż których ustawiono rząd krzeseł. W centrum sceny ustawiono palenisko. W kolejnych scenach dramatu pojedyncze przedmioty będą symbolizowały zmianę miejsca akcji - kościół i gospodę matki Turiddu. Surowa, brutalna scenografia Tramontiego i Delbona jednoznacznie zrywa z tradycja wystawień Rycerskości.

Drugie przesunięcie dotyczy chóru. W scenach zbiorowych przez szczeliny i otwory w ścianach na scenę wlewał się chór złożony z dziewięćdziesięciu pięciu śpiewaków (mieszkańców miasteczka) i wypełniał ją w całości. Tym samym chór odzyskał swoją funkcję - potężny, na co wskazywali także recenzenci premiery, nie stanowił już tła dla wydarzeń, lecz został aktywnym komentatorem wydarzeń. Gest dramaturga podkreśla gest aktora - w większości przypadków to Delbono otwiera drzwi i wpuszcza chór na scenę.

Trzecie, najważniejsze przesunięcie to wprowadzenie na scenę Bobò jako właściciela austerii prowadzonej przez Łucję - matkę Turiddu. Zmarły w 2019 roku Bobò był naturszczykiem, aktorem niezawodowym, bez wykształcenia, który wprowadza inną jakość obecności:

Każdy jego występ - pisała włoska recenzentka Rycerskości wieśniaczej - to czyste emocje. Widzimy go wśród chóru w kwiecistej koronie na głowie, gdy tymczasem Delbono rozrzuca dookoła płatki; w kościele, obok Santuzzy i Łucji, dźwiga krzyż za tych, którzy zdają się przyjmować na siebie wszystkie grzechy świata; a teraz, zasiadłszy za stołem, wznosi toast podczas wielkanocnej uczty, będącej preludium do słynnego duetu matki i syna, zanim powietrze przeszyje nieuchronnie krzyk: „Zabili Turiddu!”6.

Wybory dramaturgiczne Delbona zrywały z tradycją wystawień opery Mascagniego i były częścią strategii negocjowania charakteru miejsca, w którym przyszło pracować reżyserowi, oraz praktyk dramaturgicznych, jakie narzuca ono reżyserowi, widzom i śpiewakom.

\section{Agonistyczny teatr Delbona}

Przybliżając czytelnikom pojęcie dramaturgii przestrzeni w oparciu o propozycje teoretyczne Michela de Certeau opisane w publikacji Wynaleźć codzienność. Sztuki działania ${ }^{7}$, Wanda Świątkowska przypomina, że „prze-

${ }^{6}$ F. Motta, Punta al cuore la Cavalleria Rusticana di Pippo Delbono al Teatro San Carlo di Napoli, „Il Sole 24 ore online” 17 lipca 2012, https://www.pippodelbono.it/opera/item/38-cavalleria-rusticana.html (dostęp: 19.10.2021).

${ }^{7}$ M. de Certeau, Wynaleźć codzienność. Sztuki działania, przeł. K. Thiel-Jańczuk, Kraków 2008.

157 Ku teatrowi agonistycznemu 
strzenią można nazwać dopiero "praktykowane miejsce»". Dalej przytacza słowa badacza, który definiuje przestrzeń jako „skutek wytworzony przez działania nadające jej kierunek, szczegółowo ją opisujące, wprowadzające w wymiar czasowy oraz pozwalające jej zaistnieć jako wielofunkcyjna jedność sprzecznych programów albo umownych więzi”' . Świątkowska zwraca też uwagę na to, że:

[...] ujęcie przestrzeni publicznej [...]w kategoriach dramaturgii pozwala zobaczyć ja jako pole napięć, teren działań agonistycznych sił i pokazać ją jako strukturę dynamiczna, w której zachodzą pewne procesy. Przestrzeń w tym sensie nie jest tylko kompozycją statycznych elementów architektonicznych, ale wyłania się i kształtuje się pod wpływem działań praktykujących ją użytkowników. Dramaturgia uzmysławia ten ruch, pozwala uchwycić różne typy zachowań i praktyk, jakie wywołuje architektura, a także rozmaite relacje między zaprojektowanym miejscem a jego użytkownikami. [...] Przestrzeń nie jest tylko tłem czy „dekoracją” dla indywidualnych działań i zbiorowych przedstawień, ale aktywnym czynnikiem, który warunkuje ich przebieg i determinuje sprawczośćc ${ }^{10}$.

Jako przykład wrogiej architektury, narzucającej określone zachowania, badaczka podaje między innymi architekturę sakralna, analizowaną przez Mirosława Kocura w książce Drugie narodziny teatru... ${ }^{11}$. W przypadku monastyrów - przypomina autorka - nazwa pomieszczenia wskazuje na jego przeznaczenie. Użytkownik może z niego korzystać, o ile jego zachowanie będzie zgodne z normą narzucaną przez architekturę.

W monologach wygłaszanych w Rycerskości wieśniaczej czy prologu spektaklu Ewangelie i licznych wywiadach Delbono zwraca uwagę na problem nienaturalnych, sztucznych czy anachronicznych zachowań widzów i aktorów, kształtowanych przez określone i równie anachroniczne wyobrażenie o tym, w jaki sposób należy zachowywać się na widowni i na scenie. To, co wypada, a czego nie wypada w teatrze dramatycznym, jest niepisana umową między ludźmi, których już dawno nie ma, i ich widzami. W odniesieniu do propozycji de Certeau i analiz Świątkowskiej zaryzykowałabym tezę, że choć konwencje odeszły do lamusa, na straży dawnego porządku stoi dziś architektura: monumentalne, niemodernizowane gmachy teatrów, wznoszone w XVIII i XIX wieku, których przykładem par excellence we Włoszech są teatry operowe, zwłaszcza neapolitański San Carlo. Krzysztof

${ }^{8}$ W. Świątkowska, Dramaturgia przestrzeni, [w:] Dramaturg $w$ teatrze, literaturze, sztuce, red. W. Baluch, A. Krajewska, Poznań 2018, s. 46.

${ }^{9}$ M. de Certeau, [cyt. za:] W. Świątkowska, op. cit., s. 46.

${ }^{10}$ Ibidem, s. 56.

${ }^{11}$ M. Kocur, Drugie narodziny teatru. Performanse mnichów anglosaksońskich, Wrocław 2010. 
Warlikowski w wywiadzie dla „Rzeczpospolitej” z 2004 roku zwracał uwagę na to, że „opera jest więzieniem. Do jakiego stopnia uda się nam w nim stworzyć enklawę wolności, to problem podstawowy i najważniejszy. Zadaniem reżysera jest zaś wpuścić życie w struktury narzucone przez partyturę i skostniała konwencję" ${ }^{12}$. Wiele wskazuje na to, że i Delbono mógłby podpisać się pod tym stwierdzeniem.

Świątkowska proponuje, by w przypadkach wrogiej architektury stosować pojęcie agonu, czyli sporu dwóch postaci. Agon rozumiany jako spór dwóch postaci lub dialog protagonisty z chórem czy szerzej, już poza epoką klasyczna, konflikt pomiędzy bohaterami „stanowi podstawę konfliktu dramatycznego, zasadę rozwoju akcji” ${ }^{13}$. „Agonistyka [...] nie jest tożsama $\mathrm{z}$ antagonizmem, lecz akceptuje konflikt jako konfrontację dopuszczająca odmienne stanowiska i systemy wartości oraz rywalizację umożliwiająca postęp i rozwój”"14.

Stoję na stanowisku, że agon stanowi też centralny element dramaturgii Delbona. Z konfliktem mamy do czynienia nie tylko na płaszczyźnie słownej (częste i chętne sięganie po repertuar rewolucyjny czy bezpośrednie nawiązania w spektaklach do konfliktów zbrojnych i kulturowych we współczesnym świecie). Dramaturgia agonu jest zasadnicza „metodą" budowania przez Delbona relacji z architektura teatru operowego, śpiewakami i publicznością. W przypadku Rycerskości wieśniaczej konflikt wyzwalają trzy opisane powyżej przesunięcia; „spór” z architekturą rozgrywa się na płaszczyźnie uwspółcześnionej scenografii, ze śpiewakami - rodzi się z postawienia znaku równości między doskonalonym latami rzemiosłem a naturalną ekspresją głuchoniemego Bobò ${ }^{15}$. Widok głuchoniemego naturszczyka i „niestosownej” scenografii jest z kolei niemiłym zaskoczeniem dla publiczności. Dwa pierwsze przesunięcia (w sferze scenografii i obsady aktorskiej) stworzyły podbudowę dla trzeciego konfliktu.

Przyjmuję za de Certeau, że reżyser nie kształtuje przestrzeni, lecz jego praktyki zmieniają miejsce w przestrzeń, najczęściej wbrew intencjom architekta. Twierdzę, że ta teza jest prawdziwa w odniesieniu jeśli nie do wszystkich budynków teatralnych, to przynajmniej do tych wzniesionych w minionych wiekach, a użytkowanych do dzisiaj, które powstawały po to, by praktykować w nich określoną konwencję teatralną. Konwencje się zmieniały, lecz niekoniecznie pociagało to za sobą zmiany w architekturze

12 Za: J. Merczyński, Opera jest więzieniem, „Rzeczpospolita” 23 września 2004, nr 224.

${ }^{13}$ W. Świątkowska, op. cit., s. 55.

${ }^{14}$ Ibidem, s. 56.

${ }^{15}$ Warto zaznaczyć, że najbardziej zaciekłe spory Delbono toczył z obsadą Don Giovanniego. Spektakl, wystawiony w Poznaniu w 2014 roku, zebrał mało przychylne recenzje, a jego wywrotowy potencjał nie został właściwie oceniony. 
miejsc teatralnych. Artyści w XX wieku woleli pracować w miejscach nieteatralnych. Tymczasem $w$ teatrach miejskich architektura (celowa personifikacja) utrwalała i narzucała konwencję, a ta stawała się tradycja. W porównaniu do szkół i tradycji aktorskich zmiana tradycji wyznaczanych przez ograniczenia architektury jest dużo trudniejsza, gdyż wymaga nakładów finansowych na rewitalizację budynków. O tym, że warto o takie zmiany walczyć, świadczy na przykład Teatro Fossati w Mediolanie, wzniesiony w XIX wieku i przekształcony w 1986 roku w Teatro Studio Melato (jedną z trzech scen Piccolo Teatro w Mediolanie) - jedna z bardziej liczących się scen studyjnych we Włoszech.

\section{Reżyser wobec doświadczenia widza - widz wobec doświadczenia rzeczywistości}

Delbonowi jest bliski sposób rozumienia dramaturgii, o którym pisze Anna Krajewska, to znaczy jako „współczesnego sposobu pracy w teatrze, obejmującego i organizującego doświadczenia zachodzące zarówno po stronie sceny, jak i w planie widowni, a nawet w przestrzeniach całego teatru" ${ }^{16}$. Artysta staje wobec doświadczenia widza teatru operowego i śpiewaka, stawia diagnozę i zaleca kurację. Wielkie miasto i jego kultura - zdaje się mówić Delbono - to obok włoskiej prowincji najbardziej „niedramatyczna” część kultury. Teatr włoski to teatr repertuarowy, europejski skansen teatralny, a stali bywalcy owych - jak je nazywa Krajewska - „ostatnich bastionów spośród wszystkich sztuk, które już dawno stały się performatywne” ${ }^{17}$, patrza, ale nie widzą. Delbono przedstawia im, to znaczy stawia-przed nimi, wymusza postrzeganie i poznanie rzeczywistości. Sięgając po klasykę opery, stawia-przed nimi złożoną naturę świata, wstrząsa widzem i aktorem. Jego gest trafnie opisuje tytuł - parafraza słów Archimedesa - cytowanego tekstu Krajewskiej: Dajcie mi dramat, a poruszę świat ${ }^{18}$. Jeśli - jak pisze Dariusz Kosiński - „[...] «rzeczywistość», «życie» stanowi nieogarniony, niesłychanie złożony przepływ, który każdy z ludzi już na poziomie indywidualnym i wewnętrznym porządkuje i hierarchizuje, wybierając i montując jego poszczególne części i całostki i ich kompozycje, które następnie przechowuje, interpretuje, przekomponowuje i przekazuje sobie i innym. Ten złożony proces ma charakter dramatyczny i przedstawieniowy, zarazem zależny od uwarunkowań kulturowych i wiedzy, wyuczonych wzorców

${ }^{16}$ A. Krajewska, Dajcie mi dramat, a porusze świat, [w:] Dramaturg w teatrze, literaturze, sztuce, ed. cit., s. 217-218.

${ }^{17}$ Ibidem, s. 222.

${ }^{18}$ Ibidem, s. 207-225. 
itp." ${ }^{19}$, to Delbono dramatyzuje i przedstawia kulturę zachodnia, definiując swój artystyczny manifest poprzez negację, czym jego teatr nie jest. Robi to, korzystając z wzorców tak literackich, jak wizualnych, a także konwencji teatralnych, które rozsadza od środka, dokonując znaczących przesunięć w warstwie obsady i scenografii, a niekiedy i treści (wprowadzanie monologów odautorskich i cytatów z literatury światowej). W przypadku Rycerskości wieśniaczej najważniejsza scena operowa staje się agora, na której Dionizos oskarża Apolla o anachronizm.

Przyjmuję, że dla Delbona teatr jest miejscem życia codziennego, a jego wysiłki są nakierowane na znalezienie złotego środka między „skutecznościa, pozwalajaca na bycie zrozumianym i osiaganie założonych celów poprzez wywieranie wpływu na innych, oraz pragnieniem pozostawania we względnie ścisłej relacji z tym, co uważamy za siebie samych, niezakrywania siebie" ${ }^{20}$. Ten mechanizm ujawnia się na styku praktyki reżyserskiej i dramaturgicznej.

Delbono w teatrze operowym w Neapolu staje na pozycji słabszego, ucieka się do sztuczek i taktyk ${ }^{21}$, korzysta ze sposobności, jaką daje mu instytucja, i wyrazistym gestem reżyserskim renegocjuje kilkuwiekowa tradycję zakazów i nakazów określających to, czym jest teatr operowy we Włoszech i dla Włochów. W ten sposób negocjuje tożsamość włoskiego kulturalnego miasta.

\section{BIBLIOGRAFIA}

Bentivoglio L., Pippo Delbono. Corpi senza menzogna, Firenze 2009.

Bionda N., Gualdoni C., Visioni incociate. Pippo Delbono tra cinema e teatro, Corazzano (Pisa) 2011.

de Certeau M., Wynaleźć codzienność. Sztuki działania, przeł. K. Thiel-Jańczuk, Kraków 2008.

Kocur M., Drugie narodziny teatru. Performanse mnichów anglosaksońskich, Wrocław 2010.

Kosiński D., Performatyka. W(y)prowadzenia, Kraków 2019.

Krajewska A., Dajcie mi dramat, a poruszę świat, [w:] Dramaturg w teatrze, literaturze, sztuce, Poznań 2018, s. 207-225.

Manzella G., La possibilità della gioia, Firenze 2017.

Merczyński J., Opera jest więzieniem, „Rzeczpospolita” 23 września 2004, nr 224, http://www.encyklopediateatru.pl/artykuly/20800/opera-jest-wiezieniem (dostęp: 19.10.2021).

${ }^{19}$ D. Kosiński, Performatyka. W(y)prowadzenia, Kraków 2019, s. 39.

${ }^{20}$ Ibidem.

${ }^{21}$ Taktyka „[...] to żart «słabego» w porządku ustalonym przez «silnego», sztuka robienia sztuczek w polu innego”. Zob. M. de Certau, [cyt. za:] W. Świątkowska, op. cit., s. 49.

$161 \quad$ Ku teatrowi agonistycznemu 
Motta F., Punta al cuore la Cavalleria Rusticana di Pippo Delbono al Teatro San Carlo di Napoli, „Il Sole 24 ore online” 17 lipca 2012, https://www.pippodelbono.it/opera/ item/38-cavalleria-rusticana.html (dostęp: 19.10.2021).

Świątkowska W., Dramaturgia przestrzeni, [w:] Dramaturg w teatrze, literaturze, sztuce, red. W. Baluch, A. Krajewska, Poznań 2018, s. 45-58.

Katarzyna Woźniak - dr, Uniwersytet Wrocławski, teatrolog. Zajmuje się komparatystyką teatru. Redaktorka działu zagranicznego czasopisma „Performer” wydawanego przez Instytut im. Jerzego Grotowskiego we Wrocławiu. Tłumaczka z języka włoskiego. Autorka monografii Przed Grotowskim. Przewodnik po Wtoszech teatralnych (Kraków 2017). Ostatnio wydała pozycję Tertium datur. Jerzy Grotowski we wtoskich świadectwach i komentarzach (wyb., przekł., red. i komentarz K. Woźniak, Kraków 2020). Współredaktorka (razem z Andrea Ceccherellim) włoskiego przekładu Akropolis Jerzego Grotowskiego (A. Ceccherelli, K. Woźniak (red.), Stanisław Wyspiański, Akropolis, przeł. L. Stopponi, wst. A. Ceccherelli, posłowie D. Kosiński, przeł. K. Woźniak, Imola 2021). ORCID: 0000-0002-2683-3217. Adres e-mail: <katarzyna.wozniak3@uwr.edu.pl>.

Katarzyna Woźniak - PhD, University of Wrocław, researcher in theater studies, interested in comparative theater studies. Member of the editorial board of "Performer", the theater studies review of the Jerzy Grotowski Institute. Italian interpreter and translator. Her publications: Przed Grotowskim. Przewodnik po Wtoszech teatralnych (Kraków 2017) and Tertium datur. Jerzy Grotowski we włoskich świadectwach i komentarzach (selection, translation, editing and commentary by K. Woźniak, Kraków 2020); Co-editor (with Andrea Ceccherelli) of the Italian translation of Stanisław Wyspiański's Akropolis (A. Ceccherelli, K. Woźniak (ed.), Stanisław Wyspiański, Akropolis, translated by L. Stopponi, introduction A. Ceccherelli, afterword D. Kosiński translated by K. Woźniak, Imola 2021). ORCID: 0000-0002-2683-3217. E-mail address: <katarzyna. wozniak3@uwr.edu.pl>. 